\title{
PERAN AAUPB DALAM MEWUJUDKAN PENYELENGGARAAN PEMERINTAHAN YANG BERSIH DAN BEBAS DARI KKN
}

\author{
Agustin Widjiastuti \\ Fakultas Hukum, Universitas Pelita Harapan Surabaya \\ e-mail: agustin_natsuko@yahoo.com
}

\begin{abstract}
ABSTRAK
Penelitian ini bertujuan untuk mengetahui pelaksanaan asas-asas umum pemerintahan yang baik (AAUPB) sebagai dasar bagi penyelenggara pemerintahan untuk menjamin terwujudnya kesejahteraan warga negara. Pendekatan masalah dalam penelitian ini menggunakan Statute Approach dan Conceptual Approach. Hasil Penelitian menunjukan bahwa AAUPB dapat diibaratkan sebagai rambu lalu lintas dan pedoman perjalanan dalam rangka memperlancar hubungan pemerintahan yaitu antara pemerintah dan yang diperintah atau warga masyarakat. Apabila penyelenggara negara bertindak bebas tanpa harus terikat secara sepenuhnya kepada undang-undang maka akan membuka peluang bagi penyalahgunaan kewenangan. Di dalam penyelenggaraan negara membutuhkan adanya pembatasan kekuasaan pemerintah (negara) dengan tujuan untuk memberikan perlindungan terhadap hak-hak individu. Penyelenggara negara yang dilaksanakan oleh pemerintah sebagai unsur utama penganyom dan pelayan masyarakat mempunyai peran penting dalam mewujudkan kesejahteraan warga negaranya/masyarakat. Setiap tindakan penyelenggara pemerintah harus selalu dilaksanakan berdasarkan hukum yang berlaku, baik hukum yang tertulis maupun hukum yang tidak tertulis. Namun asas-asas umum pemerintahan tetap memiliki arti dan fungsi yang penting dalam praktik penyelenggaraan pemerintahan. Oleh karena itu, sebagai tolok ukur untuk menilai penyelenggara negara telah sesuai dalam menjalankan tindakannya dalam negara hukum, maka dapat menggunakan asas-asas umum pemerintahan yang baik.
\end{abstract}

Kata Kunci:Peran Penyelenggaraan Pemerintah, Asas-Asas Umum Pemerintahan Yang Baik, Pemerintah, Kesejahteraan Masyarakat.

\begin{abstract}
This study aims to determine the implementation of Good Governance Principles (AAUPB) as the basis for the government in performing its duties as a form of guarantee for the welfare of the citizens. This is a normative research with Statute and Conceptual Approach. Research results show that AAUPB can be likened to traffic signs and travel guidelines in order to facilitate government relations between the government and the citizens. If the state organizer acts independently without having to be fully bound by the law it will open up the opportunities of authority abuse. That's why the state administration requires such restriction of government power (state) with the aim to provide protection against the individual's rights. State organizers in this case is the government as the main element that is caring, and as a public servants have an important role in realizing the welfare of its citizens/community. Every act of government organizer shall always be carried out in accordance with the applicable law, both written law and unwritten law. However, the general principles of governance still have important meanings and functions in the governance practice. Therefore, as a benchmark to assess whether the state organizers are appropriate in carrying out their actions within the rule of law, it can use the general principles of good governance.
\end{abstract}

Keywords: The Role of Government Implementation, Common Governance Principles Good, Government, Welfare Society. 


\section{PENDAHULUAN}

Penyelenggara negara mempunyai peranan yang sangat menentukan dalam penyelenggaraan negara untuk mencapai cita-cita perjuangan bangsa mewujudkan masyarakat yang adil dan makmur sebagaimana yang termaktub dalam UndangUndang Dasar Republik Indonesia 1945 (selanjutnya disingkat UUD 1945). Penyelenggara negara adalah pejabat negara yang menjalankan fungsi eksekutif, legislatif, atau yudikatif, dan pejabat lain yang fungsi dan tugas pokoknya berkaitan dengan ketentuan peraturan perundang-undangan yang berlaku. Peran pemerintah selaku penyelenggara negara pada negara kesejahteraan sangat sentral karena diberi tugas untuk menyelenggarakan kesejahteraan rakyat. Oleh karena itu kepada pemerintah diberikan kewenangan untuk turut campur dalam segala aspek kehidupan bermasyarakat. Dengan kewajiban tersebut yang dibebankan di pundak pemerintah, pemerintah dituntut untuk terlibat secara aktif dalam dinamika kehidupan masyarakat.

Mewujudkan penyelenggara negara yang mampu menjalankan fungsi dan tugasnya secara sungguh-sungguh dan penuh tanggung jawab perlu adanya asas-asas umum penyelenggaraan negara agar dapat tercipta tata kelola pemerintahan yang baik atau good governance. Penyelenggara negara yang bersih merupakan penyelenggara negara yang menaati asas-asas umum penyelenggaraan negara dan bebas dari praktek korupsi, kolusi, dan nepotisme $(\mathrm{KKN})$, serta perbuatan tercela lainnya. Apabila penyelenggara negara bertindak bebas tanpa harus terikat secara sepenuhnya kepada undang-undang maka akan membuka peluang bagi penyalahgunaan kewenangan. Penyalahgunaan kewenangan akan membuka kemungkinan benturan kepentingan antara penyelenggara negara dengan rakyat yang merasa dirugikan akibat penyalahgunaan kewenangan tersebut. Sehingga di dalam penyelenggaraan negara membutuhkan adanya pembatasan kekuasaan pemerintah atau negara dengan tujuan untuk memberikan perlindungan terhadap hak-hak individu.

Tidak ada kekuasaan negara yang boleh dibiarkan bebas tanpa adanya pembatasan dan pengawasan. Sehingga diperlukan adanya berbagai macam cara, prosedur, asas, atau sistem yang dikembangkan dalam berbagai sistem ketatanegaraan. Sistem pembatasan kekuasaan, asas legalitas, mekanisme hak uji materi, ataupun peradilan administrasi negara merupakan contoh berbagai asas, sistem atau prosedur pembatasan kekuasaan negara yang dimaksud. Untuk menilai apakah tindakan pemerintah sejalan dengan asas negara hukum atau tidak, dapat menggunakan asas-asas umum pemerintahan yang baik. ${ }^{1}$

Asas-asas umum pemerintahan yang baik (selanjutnya disebut AAUPB) lahir dari praktik penyelenggaraan negara dan pemerintahan sehingga bukan produk formal suatu lembaga negara seperti undang-undang. Asas-asas umum pemerintahan yang baik dapat dipahami sebagai asas-asas umum yang dijadikan sebagai dasar dan tata cara dalam penyelenggaraan pemerintahan yang layak, yang dengan cara demikian penyelenggaraan pemerintahan itu menjadi baik, sopan, adil, dan terhormat, bebas dari kezaliman, pelanggaran peraturan, tindakan penyalahgunaan wewenang dan tindakan sewenangwenang.

Mendasarkan pada pendapat Jazim Hamidi bahwa: Pertama, AAUPL merupakan nilai-nilai etik yang hidup dan berkembang dalam lingkungan Hukum Administrasi Negara, dan berfungsi sebagai pegangan bagi para pejabat administrasi negara dalam menjalankan fungsinya, merupakan alat uji bagi hakim administrasi dalam menilai tindakan administrasi negara (yang berwujud penetapan atau beschikking) dan sebagai dasar pengajuan gugatan bagi pihak penggugat. Kedua, Sebagian besar dari AAUPB masih merupakan asas-asas yang tidak tertulis, masih abstrak, dan dapat digali dalam praktik kehidupan di masyarakat, dan Sebagian asas yang lain sudah menjadi kaidah hukum tertulis dan terpencar dalam berbagai peraturan hukum positif. ${ }^{2}$

Konsepsi AAUPB menurut Crince Le Roy yang meliputi: asas kepastian hukum, asas keseimbangan, asas bertindak cermat, asas motivasi untuk setiap keputusan badan pemerintah, asas tidak boleh mencampuradukkan kewenangan, asas kesamaan dalam pengambilan keputusan, asas permainan yang

\footnotetext{
${ }^{1}$ Ridwan HR, Hukum Administrasi Negara, Rajagrafindo Persada, Jakarta, 2008, h. 242.

2 Jazim Hamidi, Penerapan Asas-asas Umum Penyelenggaraan Pemerintahan Yang Layak (AAUPL) di Lingkungan Peradilan Administrasi Indonesia, Citra Aditya Bakti, Bandung, 1999, h. 24, terjemahan Nomensen Sinano, Hukum Administrasi Negara, Jala Permata Aksara, Jakarta, 2010, h. 142 .
} 
layak, asas keadilan atau kewajaran, asas menanggapi pengharapan yang wajar, asas meniadakan akibat-akibat suatu keputusan yang batal, dan asas perlindungan atas pandangan hidup pribadi. Koentjoro menambahkan dua asas lagi, yakni: asas kebijaksanaan dan asas penyelenggaraan kepentingan umum. $^{3}$

Asas-asas umum pemerintahan yang baik sebagai sebuah norma telah diintrodusir dalam praktek penyelenggaraan pemerintahan sebagaimana termuat dalam ketentuan Pasal 3 jo Pasal 1 angka 1 UndangUndang No. 28 Tahun 1999 tentang Penyelenggaraan Negara yang Bersih dan Bebas dari Korupsi, Kolusi dan Nepotisme, yaitu sebagai berikut:

Pertama, Asas Kepastian Hukum, merupakan asas dalam negara hukum yang mengutamakan landasan peraturan perundang-undangan, kepatutan, dan keadilan dalam setiap kebijakan penyelenggara negara.

Kedua, Asas Tertib Penyelenggaraan Negara, merupakan asas yang menjadi landasan keteraturan, keserasian, dan keseimbangan dalam pengendalian penyelenggaraan negara.

Ketiga, Asas Kepentingan Umum, merupakan asas yang mendahulukan kesejahteraan umum dengan cara yang aspiratif, akomodatif, dan selektif.

Keempat, Asas Keterbukaan, merupakan asas yang membuka diri terhadap hak masyarakat untuk memperoleh informasi yang benar, jujur, dan tidak diskriminatif tentang penyelenggaraan negara dengan tetap memperhatikan perlindungan atas hak asasi pribadi, golongan, dan rahasia negara.

Kelima, Asas Proporsionalitas, adalah asas yang mengutamakan keseimbangan antara hak dan kewajiban penyelenggara negara.

Keenam, Asas Profesionalitas, merupakan asas yang mengutamakan keahlian yang berlandaskan kode etik dan ketentuan peraturan perundangundangan yang berlaku.

Ketujuh, Asas Akuntabilitas, merupakan asas yang menentukan bahwa setiap kegiatan dan hasil akhir dari kegiatan penyelenggara negara harus dapat dipertanggungjawabkan kepada masyarakat atau rakyat sebagai pemegang kedaulatan tertinggi

\footnotetext{
${ }^{3}$ Kuntjoro Purbopranoto, Beberapa Catatan Hukum Tata Pemerintahan dan Peradilan Administrasi Negara, Bina Cipta, Bandung, 1975, h. 29-30.
}

negara sesuai dengan ketentuan peraturan perundangundangan yang berlaku.

Selain di dalam Undang-Undang No. 28 Tahun 1999, AAUPB banyak ditemukan dalam beberapa peraturan perundang-undangan di Indonesia, di antaranya dalam penjelasan Pasal 53 ayat (2) UndangUndang No. 9 Tahun 2004 dan bertebaran di beberapa peraturan perundang-undangan dan yurisprudensi. Karena itu asas yang telah dijabarkan dalam beberapa UU dan yurispridensi tersebut tidak saja memiliki daya mengikat secara moral dan doktrinal, tapi juga mempunyai daya mengikat secara yuridis. ${ }^{4}$

AAUPB lahir dari praktik penyelenggaraan negara dan pemerintahan. Pada awalnya, AAUPB dimaksudkan sebagai sarana perlindungan hukum atau rechtsbescherming, dan bahkan dijadikan sebagai instrumen untuk peningkatan perlindungan hukum atau verhoodge rechtsbescherming bagi warga negara dari tindakan pemerintah. AAUPB selanjutnya dijadikan sebagai dasar penilaian dalam peradilan dan upaya administrasi, di samping sebagai norma hukum tidak tertulis bagi tindakan pemerintahan. ${ }^{5}$

Fungsi AAUPB dalam penyelenggaraan pemerintahan adalah sebagai pedoman atau penuntun bagi pemerintah atau pejabat administrasi negara dalam rangka pemerintahan yang baik atau good governance. Muin Fahmal menegaskan bahwa asas umum pemerintahan yang layak sesungguhnya adalah rambu-rambu bagi para penyelenggara negara dalam menjalankan tugasnya. Rambu-rambu tersebut diperlukan agar tindakan-tindakannya tetap sesuai dengan tujuan hukum yang sesungguhnya. ${ }^{6}$ Mendasarkan pendapat SF. Marbun, AAUPB memiliki arti penting dan fungsi berikut: ${ }^{7}$

Pertama, Bagi administrasi negara, bermanfaat sebagai pedoman dalam melakukan penafsiran dan penerapan terhadap ketentuan-ketentuan perundangundangan yang bersifat samar atau tidak jelas.

\footnotetext{
${ }^{4}$ S.F. Marbun, Peradilan Administrasi Negara dan Upaya Administratif di Indonesia, Cet. III, FH UII Press, Yogyakarta, 2011, h. 378-379.

${ }^{5}$ Ridwan HR., Op.Cit., h. 251.

${ }^{6}$ Muin Fahmal, Peran Asas-asas Umum Pemerintahan yang Layak dalam Mewujudkan Pemerintahan yang Bersih, UII Press, Yogyakarta, 2008, h. 60.

${ }^{7}$ Nomensen Sinamo, Hukum Administrasi Negara, Jala Permata Aksara, Jakarta, 2010, h. 142-143.
} 
Kedua, Bagi warga masyarakat, sebagai pencari keadilan, AAUPB dapat dipergunakan sebagai dasar gugatan sebagaimana disebutkan dalam Pasal 53 Undang-Undang No. 5 Tahun 1986.

Ketiga, Bagi hakim Tata Usaha Negara (TUN), dapat dipergunakan sebagai alat menguji dan membatalkan keputusan yang dikeluarkan badan atau pejabat TUN.

Keempat, Selain itu, AAUPB tersebut juga berguna bagi badan legislatif dalam merancang suatu undang-undang.

AAUPB atau layak dipandang sebagai bagian dari hukum positif, baik sebagai hukum positif tidak tertulis maupun hukum positif yang tertulis. Perumusan AAUPB beserta perincian asas-asasnya secara lengkap memang tidak dikumpulkan dan dituangkan secara konkret dan formal dalam bentuk suatu peraturan perundang-undangan khusus tentang AAUPB sebab asas-asas yang bersangkutan justru merupakan kaidah hukum tidak tertulis sebagai pencerminan norma-norma etis berpemerintahan yang wajib diperhatikan dan dipatuhi di samping mendasarkan pada kaidah-kaidah hukum tertulis. ${ }^{8}$

\section{PERUMUSAN MASALAH}

Bertolak dari uraian latar belakang masalah, maka dapat dirumuskan permasalahan, yaitu bagaimana penggunaan asas asas umum pemerintahan yang baik dalam penyelenggaraan pemerintahan yang bebas dan bersih dari KKN dalam rangka mewujudkan kesejahteraan warga negara.

\section{METODE PENELITIAN}

Penelitian ini menggunakan penelitian normatif, merupakan upaya mencari penyelesaian masalah dengan meneliti dan mengkaji norma hukum positif dengan menggunakan konsep Law in book, yaitu dengan melakukan studi kepustakaan.

Pendekatan masalah dalam penelitian ini menggunakan Statute Approach dan Conceptual Approach. Statute Approach adalah pendekatan dengan menelaah semua undang-undang dan regulasi yang bersangkut paut dengan isu hukum yang

\footnotetext{
${ }^{8}$ Paulus Efendi Lotulung, Himpunan Asas-Asas Umum Pemerintahan yang Baik (AAUPB), Citra Aditya Bakti, Bandung, 1994, h. 14.
}

sedang ditangani. ${ }^{9}$ Sedangkan Conceptual Approach adalah pendekatan dengan mengidentifikasikan dan membahas pandangan-pandangan dan doktrindoktrin yang berkembang dalam ilmu hukum. ${ }^{10}$

Bahan atau sumber hukum yang digunakan dalam penelitian ini dapat dibedakan sebagai berikut: Pertama, Bahan hukum primer, yang merupakan bahan hukum yang sifatnya mengikat, berupa peraturan perundang-undangan, dalam hal ini yakni UUD 1945, Undang-Undang No. 28 Tahun 1999 tentang Penyelenggaraan Negara yang Bersih dan Bebas dari Korupsi, Kolusi, dan Nepotisme. Kedua, Bahan hukum sekunder, yang erat kaitannya dengan bahan hukum primer karena menjelaskan bahan hukum primer, antara lain literatur tentang asas asas umum pemerintahan yang baik dan tentang asas negara hukum khususnya mengenai peraturan kebijakan.

\section{PEMBAHASAN}

\section{Peran dan Pengertian AAUPB sebagai Sarana Penyelenggaraan Pemerintahan}

Dalam rangka mewujudkan penyelenggaraan pemerintahan yang baik, maka penyelenggara harus mampu menjalankan fungsi dan tugasnya secara sungguh-sungguh dan penuh tanggung jawab. Oleh karenanya perlu didasarkan pada asas asas penyelenggaraan negara. Setiap tindakan penyelenggara pemerintah harus selalu dilaksanakan berdasarkan hukum yang berlaku, baik hukum yang tertulis maupun hukum yang tidak tertulis dengan tidak membedakan golongan, suku, agama dan bahkan status sosial. Terkait dengan penyelenggaraan pemerintahan ada beberapa prinsip dasar yang menjadi pegangan oleh aparat pemerintahan dalam menggerakan administrasi pemerintahan. Untuk mewujudkan penyelenggaraan pemerintahan yang baik tidak boleh bertentangan dengan AAUPB.

AAUPB merupakan hukum yang tidak tertulis. Istilah AAUPB berasal dari kata bahasa Belanda algemene begineselen van behoorlijk bestuur. ${ }^{11}$ Dalam bahasa Indonesia diterjemahkan secara beragam, misalnya dasar-dasar pemerintahan yang

\footnotetext{
${ }^{9}$ Peter Mahmud Marzuki, Penelitian Hukum, Cetakan VI, Kencana Prenada Media Group, Jakarta, 2010, h. 93.

${ }^{10}$ Ibid., h. 95.

${ }^{11}$ Ridwan HR, Hukum Administrasi Negara, UII Pres, Yogyakarta, 2002, h. 182, terjemahan Aan Efendi, Buku Ajar Acara Peradilan Tata Usaha Negara, UNEJ, Jember, 2011, h. 53.
} 
baik, asas-asas pemerintahan yang baik, asas-asas pemerintahan yang layak, asas-asas pemerintahan yang patut dan sebagainya. ${ }^{12}$ Asas mengandung beberapa arti, asas dapat mengandung arti sebagai dasar (sesuatu yang menjadi tumpuan berpikir atau berpendapat), dasar cita-cita (perkumpulan atau organisasi), hukum dasar. Jika bertitik tolak dari arti harafiah asas yang dikemukakan di atas, AAUPB dapat dipahami sebagai dasar umum dalam penyelenggaraan pemerintahan yang baik. Namun, pengertian seperti yang dikemukakan di atas tidak akan menambah pemahaman atau pengetahuan mengenai asas-asas umum pemerintahan yang baik. Oleh sebab itu, pengertian yang diperoleh dengan hanya bertitik tolak dari penafsiran gramatikal seperti dikemukakan di atas tidak cukup memadai. Untuk dapat lebih baik memahami pengertian dan fungsi AAUPB dalam praktik penyelenggaraan pemerintahan dan hukum administrasi negara, maka perlu dilakukan pendekatan yang lain. Adapun pendekatan tersebut dengan menggunakan, metode penafsiran gramatikal seperti dikemukakan di atas, perlu ada pendekatan lain untuk menambah wawasan dan pemahaman mengenai asas-asas umum pemerintahan yang baik tersebut. Salah satu alternatif yang dapat dikemukakan adalah metode pendekatan historis.

Hotma P. Sibuea mengemukakan AAUPB lahir dari praktik penyelenggaraan negara dan pemerintahan sehingga bukan produk formal suatu negara seperti undang-undang. AAUPB lahir sesuai dengan perkembangan zaman untuk meningkatkan perlindungan terhadap hak-hak individu. Fungsi AAUPB dalam penyelenggaraan pemerintahan adalah sebagai pedoman atau penuntun bagi pemerintah atau pejabat administrasi negara dalam rangka pemerintahan yang baik atau good governance. ${ }^{13}$

Seperti yang telah diutarakan oleh Muin Fahmal pada uraian sebelumnya bahwa asas-asas umum pemerintahan yang layak (AAUPL) sebagai rambu bagi pemerintah atau penyelenggara negara di dalam melaksanakan tugasnya, dengan tujuan semua tindakan pemerintah/penyelenggara negara

\footnotetext{
${ }^{12}$ Aan Efendi, Ibid.

13 Hotma P. Sibuea, Asas Negara Hukum Peraturan Kebijakan dan Asas-asas Umum Pemerintahan yang Baik, Erlangga, Jakarta, 2002, h. 151.
}

dalam melakukakan tugasnya akan sesuai dengan rambu-rambu yang telah dicantumkan dalam asasasas umum pemerintahan yang layak.

Sebagai rambu-rambu penyelenggaraan, AAUPB pada awalnya bukan merupakan sekumpulan normanorma hukum, tetapi sekumpulan prinsip yang bertendensi atau bermuatan etis. Dengan perkataan lain, AAUPB pada awalnya merupakan etika penyelenggaraan pemerintahan. Selanjutnya Ridwan HR mengemukakan AAUPB bahwa asas-asas umum yang dijadikan sebagai dasar dan tata cara dalam penyelenggaraan pemerintahan yang layak, yang dengan cara demikian penyelenggaraan pemerintahan itu menjadi baik, sopan, adil, terhormat, bebas dari kezaliman, pelanggaran peraturan, tindakan penyalahgunaan wewenang dan tindakan sewenangwenang. ${ }^{14}$ Wiarda, seperti dikutip Ateng Syarifuddin, mengemukakan AAUPL berlaku sebagai tendensitendensi etik yang menjadi dasar hukum bagi tata usaha negara baik yang tertulis ataupun yang tidak tertulis, termasuk praktik pemerintahan. ${ }^{15}$ Sebagai tendensi etis, kekuatan mengikat asas-asas umum pemerintahan lemah jika dibandingkan dengan kekuatan mengikat norma-norma hukum. Etika tidak memiliki kemampuan memaksa yang kuat seperti norma-norma hukum karena etika tidak ditegakkan oleh kekuasaan negara, tetapi oleh kesadaran masing-masing individu. Namun, meskipun AAUPB hanya merupakan tendensi-tendensi etik dan bukan merupakan norma-norma hukum seperti dikemukakan Wiarda, asas-asas umum pemerintahan tetap memiliki arti dan fungsi yang penting dalam praktik penyelenggaraan pemerintahan. Dengan perkataan lain, meskipun AAUPB bersifat normatif hanya secara etika, asas-asas tersebut tetap dapat berfungsi sebagai pedoman yang penting bagi pemerintah dan para penjabat administrasi negara dalam menetapkan suatu kebijakan.

Pada kenyataannya, AAUPB ini meskipun merupakan asas, namun tidak semuanya merupakan pemikiran yang umum dan abstrak, dan dalam beberapa hal muncul sebagai aturan hukum yang konkrit atau tertuang secara tersurat dalam pasal

${ }^{14}$ Ridwan HR, Op.Cit., h. 183-184.

${ }^{15}$ Ateng Syarifuddin, Asas-asas Pemerintahan yang Layak bagi Pengabdian Kepala Daerah, dalam Paulus Efendi Lotulung, Himpunan Asas-asas Umum Pemerintahan yang Baik (AAUPB), Citra Aditya Bakti, Bandung, 1994, h. 37. 
undang-undang serta mempunyai sanksi hukum. Dengan demikian, asas-asas umum pemerintahan yang baik tersebut dapat dipakai sebagai penuntun bagi para penyelenggara pemerintahan atau pejabat administrasi negara dalam penyelenggaraan tugastugas pemerintahan supaya pemerintah dan pejabat administrasi negara tidak melakukan tindakan yang dapat menimbulkan kerugian terhadap warga negara. AAUPB akan berfungsi sebagai penuntun jika pejabat administrasi negara menerapkan kebijakan yang tidak bertentangan dengan AAUPB tersebut.

Terkait dengan pernyataan tersebut di atas, menurut Jazim Hamidi, AAUPB memiliki 4 pengertian. Didasarkan dari pengertian AAUPB menurut beliau bahwa AAUPB di samping merupakan nilai etik yang dapat berfungsi sebagai pegangan bagi pejabat pemerintah atau penyelenggara negara dalam melaksanakan tugas dan fungsinya juga merupakan asas-asas yang tidak tertulis dalam dapat digali atau dicari dalam kehidupan masyarakat selain asas lain yang telah menjadi kaidah hukum tertulis dan telah tersebar pada berbagai peraturan hukum positif atau hukum yang berlaku di suatu negara.

Dengan demikian AAUPB pada hakekatnya dapat dipergunakan sebagai salah satu dasar untuk menguji bagi penyelesai atau hakim apakah perbuatan pemerintahan yang telah dilakukan sesuai dengan peraturan perundang-undangan tertulis, yang menyangkut wewenang, prosedur dan substansi serta kesesuaian menyangkut pedoman-pedoman yang tidak tertulis yakni AAUPB tersebut. ${ }^{16}$ Dalam perkembangannya asas-asas umum pemerintahan yang baik terbagi menjadi dua yaitu sebagai dasar penilaian bagi hakim dan sebagai norma pengarah bagi organ pemerintahan, sehingga AAUPB memiliki arti penting dan fungsi sebagai berikut:

Pertama, Bagi administrasi negara, bermanfaat sebagai pedoman dalam melakukan penafsiran dan penerapan terhadap ketentuan-ketentuan perundangundangan yang bersifat sumir, samar, atau tidak jelas. Selain itu sekaligus membatasi dan menghindari kemungkinan administrasi negara mempergunakan fries ermessen atau melakukan kebijaksanaan yang jauh menyimpang dari ketentuan perundangundangan. Dengan demikian administrasi negara diharapkan terhindar dari perbuatan onrechtmatige

${ }^{16}$ Lutfi Effendi, Pokok-Pokok Hukum Administrasi, Bayu Media, Malang, 2004, h. 82. daad, detournement de pouvoir, abus de droit, dan ultravires.

Kedua, Bagi warga masyarakat, sebagai pencari keadilan, AAUPL dapat dipergunakan sebagai dasar gugatan sebagaimana disebutkan dalam Pasal 53 Undang-Undang No. 5 Tahun 1986.

Ketiga, Bagi hakim TUN, dapat dipergunakan sebagai alat menguji dan membatalkan keputusan yang dikeluarkan badan atau pejabat TUN.

Keempat, AAUPL tersebut juga berguna bagi badan legislatif dalam merancang suatu undangundang. ${ }^{17}$

Didasarkan dari beberapa pendapat para pakar dan perkembangan dari AAUPB, maka akan muncul perbedaan-perbedaan, hal ini disebabkan karena lahirnya AAUPB itu sendiri dari proses sejarah hingga perkembangannya sudah berbeda termasuk perbedaan dengan asas yang lahir yang ada di negara asalnya. Oleh karenanya AAUPB dapat diibaratkan sebagai rambu lalu lintas dan pedoman perjalanan dalam rangka memperlancar hubungan pemerintahan yaitu antara pemerintah dan yang diperintah atau warga masyarakat. Asas pemerintahan ini bersifat normatif yang bersumber dari sistem nilai dan etika pemerintahan dan menjadi pegangan penyelenggara dalam menjalankan pemerintahan.

Dengan dipenuhinya dan dilaksanakannya AAUPB dalam penyelenggaran pemerintahan maka diharapkan adanya masyarakat yang madani. Terkait dengan harapan tersebut di atas, menurut Mustopadidjaja yang dimaksud dengan masyarakat madani ialah suatu tatanan masyarakat yang memiliki nilai-nilai dasar ketuhanan, kemerdekaan, hak asasi manusia dan martabat manusia, kebangsaan, demokrasi, kemajemukan, kebersamaan, persatuan dan kesatuan, kesejahteraan bersama, keadilan, supremasi hukum, keterbukaan, partisipasi, kemitraan, rasionalitas etis, perbedaan pendapat dan pertanggungjawaban (akuntabilitas), yang seharusnya harus melekat pada setiap individu dan instansi yang memiliki komitmen untuk mewujudkannya. Nilai-nilai masyarakat madani tersebut harus mampu diwujudkan sebagai upaya

${ }^{17}$ S.F. Marbun, "Menggali dan Menemukan Asas-asas Umum Pemerintahan yang Baik di Indonesia", tulisan pada Dimensi-Dimensi Pemikiran Hukum Administrasi Negara, UII Pres, Yogyakarta, 2001, h. 210-211. Di dalam Disertasinya, SF. Marbun, menguraikan secara panjang lebar mengenai catur fungsi dari AAUPL ini, lihat h. 122-149. 
reformasi nasional penyelenggaraan negara guna menyeimbangkan posisi dan peran pemerintah dunia usaha dan masyarakat dalam kehidupan berbangsa dan bernegara. ${ }^{18}$

Didasarkan dari uraian tersebut di atas, dengan melaksanakan AAUPB pemerintah dapat mengurangi peranannya dan memberikan kesempatan kepada warga masyarakat untuk ikut berpartisipasi dalam pembangunan, sehingga perlu adanya pemberdayaan masyarakat. Tatiek Sri Djatmiati menyatakan bahwa AAUPB merupakan salah satu parameter legalitas. Jadi frasa peraturan peraturan perundangundangan yang berlaku dalam Pasal 19 UU PTUN sudah tepat dan tidak berguna dengan menambah AAUPB. ${ }^{19}$ Selanjutnya menurut Hari Sugiharto menyatakan bahwa Badan/Pejabat Pemerintah dalam menggunakan wewenang harus berdasarkan peraturan perundang-undangan dan AAUPB. ${ }^{20}$

\section{Macam-macam AAUPB dalam Pelaksanaannya}

Sebagaimana dikemukakan sebelumnya, konsekuensi terhadap peranan dan aktivitas pemerintah dalam penyelenggaraan pemerintahan, maka peranan pemerintah pada negara kesejahteraan sangat sentral karena diberi tugas untuk menyelenggarakan kesejahteraan rakyat. Untuk keperluan-keperluan penyelenggaraan kesejahteraan itu, kepada pemerintah diberikan kewenangan untuk turut campur dalam segala aspek kehidupan bermasyarakat tanpa harus mengurangi perananan dari masyarakat. Dengan kewajiban yang dibebankan di pundak pemerintah seperti dikemukakan di atas,

\footnotetext{
${ }^{18}$ Asmawi Rewansyah, Reformasi Birokrasi dalam Rangka Good Governance, Yusaintanas Prima, Jakarta, 2010, h. 99, dikutip dari AR Mustopadidjaja, Dimensi-Dimensi Pokok Sistem Administrasi Negara Kesatuan Republik Indonesia, Cetakan Kelima, Duta Pertiwi Foundation, Jakarta, 2005.

19 Tatiek Sri Djatmiati, "Peradilan Tata Usaha Negara dalam Konteks Undang-Undang No. 30 Tahun 2014 tentang Administrasi Pemerintahan”, dalam Makalah yang disampaikan pada Seminar Nasional Kewenangan PTUN Pasca Diundangkannya UU AP No. 30 Tahun 2014, diselenggarakan FH Unair, 29 Agustus 2016, Surabaya, h. 4.

${ }^{20}$ Hari Sugiharto, "Pemeriksaan Hakim PTUN Terhadap Perluasan (Expantion) Kewenangan PTUN Sebagai Implementasi UU No. 30 Tahun 2014 tentang Administrasi Pemerintahan", dalam Makalah yang disampaikan pada Seminar Nasional dengan tema Aspek Kewenangan Peradilan Tata Usaha Negara Pasca Diundangkannya Undang-Undang Nomor 30 Tahun 2014 tentang Administrasi Pemerintahan, diselenggarakan FH Unair, 29 Agustus 2016, Surabaya, h. 1.
}

pemerintah dituntut untuk terlibat secara aktif dalam dinamika kehidupan masyarakat.

Pada asasnya, setiap bentuk campur tangan pemerintah dalam pergaulan sosial harus berpedoman pada peraturan perundang-undangan sesuai dengan tuntutan asas legalitas sebagai konsekuensi dari asas negara hukum. Namun, kelemahan asas legalitas yang sangat mengutamakan kepastian hukum mengakibatkan asas ini cenderung membuat pemerintah menjadi lamban dalam bertindak. Oleh karena itu, pemerintah diberi kewenangan untuk bertindak atas inisiatif sendiri untuk menyelesaikan persoalan-persoalan yang pada dasarnya belum ada aturannya. Dengan demikian, Markus Lukman mengemukakan bahwa freis ermessen merupakan salah satu sarana yang memberikan ruang bergerak bagi pejabat atau badan-badan administrasi negara untuk melakukan tindakan tanpa harus terikat sepenuhnya kepada pada undang-undang. ${ }^{21}$

Kebebasan bertindak pejabat administrasi negara tanpa harus terikat secara sepenuhnya kepada undang-undang seperti disebut di atas secara teoritis ataupun dalam kenyataan praktik pemerintahan ternyata membuka peluang bagi penyalahgunaan kewenangan. Penyalahgunaan kewenangan akan membuka kemungkinan benturan kepentingan antara pejabat administrasi negara dengan rakyat yang merasa dirugikan akibat penyalahgunaan kewenangan tersebut. Oleh karena itu, HR. Ridwan menyatakan untuk menilai apakah tindakan pemerintah sejalan dengan asas negara hukum atau tidak, dapat menggunakan AAUPB. ${ }^{22}$

AAUPB sejak dahulu sudah dikenal di beberapa negara. Namun, perhatian terhadap AAUPB tersebut baru mulai meningkat pada pertengahan abad ke-20. Di negeri Belanda, AAUPB disebut dengan istilah Algemene Beginselen van Berhoorlyk Bestuur; sedangkan di Perancis dikenal dengan nama les principles du droit constumeir publique. AAUPB merupakan konsep yang terbuka dan lahir dari suatu proses sejarah, sehingga terdapat beragam rumusan mengenai asas-asas tersebut. Di antara para sarjana yang mengetengahkan tentang AAUPB adalah Crince

21 Markus Lukman, "Freis Ermessen dalam Proses Perencanaan dan Pelaksanaan Rencana Kota di Kotamadya Pontianak", Tesis tidak diterbitkan, Universitas Padjadjaran, Bandung, 1989, h. 205.

${ }^{22}$ Ridwan HR, Op.Cit., h. 242. 
Le Roy mengemukakan sebelas umum pemerintahan yang baik dalam lapangan hukum administrasi dan praktik penyelenggaraan pemerintahan di Belanda. Asas-asas umum pemerintahan yang baik dikemukakan oleh Crince Le Roy tersebut meliputi: Asas kepastian hukum (principle of legal security); Asas keseimbangan (principle of proportionality); Asas kesamaan dalam mengambil keputusan (principle of equalty); Asas bertindak cermat (principle of carefulness); Asas motivasi dalam setiap keputusan (principle of motivation); Asas larangan mencampuradukkan kewenangan (principle of non-misuse of competence); Asas permainan yang layak (principle of fairplay); Asas keadilan atau kewajaran (principle of reasonable of prohibition of arbitrariness); Asas menanggapi penghargaan yang wajar (principle of meeting raised expectation); Asas meniadakan akibat keputusan yang batal (principle of undoing the consequence of unnudell edcision); Asas perlindungan atas pandangan (cara) hidup pribadi (principle of protecting the personal way of life) ${ }^{23}$

Menurut Kuncoro Purbopranoto, AAUPB dikategorikan dapat dalam 13 (tiga belas) asas yaitu: Asas kepastian hukum (principle of legal security); Asas keseimbangan (principle of proporcionalitas); Asas kesamaan dalam mengambil keputusan (principle of equality); Asas bertindak cermat (principle of carefulness); Asas motivasi untuk setiap keputusan (principle of motivation); Asas jangan mencampuradukkan kewenangan (principle of non misuse of competence); Asas permainan yang layak (principle of fair play); Asas keadilan atau kewajaran (principle of reasonableness or prohition of arbitrariness); Asas menanggapi penghargaan yang wajar (principle of meeting raised expectation); Asas meniadakan akibat-akibat suatu keputusan yang batal (principle of undoing the consequences of an annulled decision); Asas perlindungan atas pandangan hidup (cara hidup) pribadi (principle of protecting the personal way oflive); Asas kebijaksanaan (sapientia); Asas penyelenggaraan kepentingan umum (principle of public service).$^{24}$

Indroharto dengan mengutip pendapat dari W. Konijnenbelt dalam bukunya Hoofdlijen van

\footnotetext{
${ }^{23}$ Hotma P. Sibuea, Op.Cit., h. 158.

${ }^{24}$ Kuntjoro Purbopranoto, Beberapa Catatan Hukum Tata Pemerintahan dan Peradilan Administrasi Negara, Jilid II, Alumni, Bandung, 1981, h. 29-30.
}

Administratiefrecht mengetengahkan AAUPB sebagai berikut: Pertama, Asas-asas formal mengenai pembentukan keputusan: a. Asas kecepatan formal; b. Asas fair play. Kedua, Asas-asas formal mengenai formulasi keputusan: a. Asas pertimbangan; b. Asas kepastian hukum formal. Ketiga, Asas-asas materiel mengenai isi keputusan: a. Asas kepastian hukum material; b. Asas kepercayaan atau asas harapanharapan yang telah ditimbulkan; c. Asas persamaan; d. Asas kecermatan material; e. Asas keseimbangan. ${ }^{25}$

Menurut SF Marbun asas-asas umum pemerintahan Indonesia yang adil dan patut dirinci sebagai berikut: Asas persamaan; Asas keseimbangan, keserasian dan keselarasan; Asas menghormati dan memberikan haknya setiap orang; Asas ganti rugi karena kesalahan; Asas kecermatan; Asas kepastian hukum; Asas kejujuran dan keterbukaan; Asas larangan menyalahgunakan wewenang; Asas larangan sewenang-wenang; Asas kepercayaan atau penghargaan; Asas motivasi; Asas kepantasan atau kewajaran; Asas pertanggungjawaban; Asas kepekaan; Asas penyelenggaraan kepentingan umum; Asas kebijaksanaan; Asas itikad baik. ${ }^{26}$

Didasarkan pada definisi 4 (empat) sarjana tersebut di atas, muncul perbedaan-perbedaan tentang rumusan AAUPB antara sarjana Indonesia dan sarjana di luar Indonesia. Khususnya tentang asas penyelenggaraan kepentingan umum dan asas kebijaksanaan, kedua asas ini hanya dikenal di Indonesia. Asas ini menghendaki agar pemerintah dalam melaksanakan tugasnya selalu harus mengutamakan kepentingan umum dan kemanfaatan umum yaitu harus memberikan dampak pada peningkatan kesejahteraan dan kepentingan yang mencakup kehidupan orang banyak/warga masyarakat.

Penyelenggaraan kepentingan umum dapat berwujud hal-hal di antaranya: pertama, Memelihara kepentingan umum yang khusus mengenai kepentingan negara, di mana contohnya tugas pertahanan dan keamanan; kedua, Memelihara kepentingan umum dalam arti kepentingan bersama dari warga negara yang tidak dapat dipelihara oleh

${ }^{25}$ Indroharto, Usaha Memahami Undang-Undang tentang Peradilan Tata Usaha Negara, Buku II Beracara di Pengadilan Tata Usaha Negara, Pustaka Sinar Harapan, Jakarta, 2005, h. 178-183.

${ }^{26}$ SF. Marbun, Peradilan Administrasi Negara dan Upaya Administratif di Indonesia, Liberty, Yogyakarta, 1997, h. 235. 
warga negara sendiri yang contohnya adalah persediaan sandang, pangan, perumahan, kesejahteraan, dan lain-lain; ketiga, Memelihara kepentingan bersama yang tidak seluruhnya dapat dilakukan oleh para warga negara sendiri, dalam bentuk bantuan negara. Contohnya pendidikan dan pengajaran, kesehatan, dan lain-lain; keempat, Memelihara kepentingan dari warga negara perseorangan yang tidak seluruhnya dapat diselenggarakan oleh warga negara sendiri, dalam bentuk bantuan negara karena adakalanya negara memelihara seluruh kepentingan perorangan tersebut yang contohnya adalah pemeliharaan fakir miskin, anak yatim, anak cacat, dan lain-lain; kelima, Memelihara ketertiban, keamanan, dan kemakmuran setempat, yang contohnya adalah peraturan lalu lintas, pembangunan, perumahan, dan lain-lain. ${ }^{27}$

Selanjutnya mengenai asas kebijaksanaan dalam hal ini menghendaki pemerintah dalam melaksanakan tugas dan fungsinya harus diberi kebebasan dan keleluasaan dalam menerapkan kebijaksanaan. Di Indonesia asas kebijaksanaan berimplikasi tiga unsur yaitu: Pengetahuan yang tandas dan analisis situasi yang dihadapi; Rancangan penyelesaian atas dasar staatsidee ataupun rechtsidee yang disetujui bersama yaitu Pancasila; Mewujudkan rancangan penyelesaian untuk mengatasi situasi dengan tindakan perbuatan dan penjelasan yang tepat, yang dituntut oleh situasi yang dihadapi. ${ }^{28}$

Selanjutnya AAUPB terkait dengan putusan PTUN, maka fungsi dari AAUPB adalah untuk menguji keabsahan KTUN bebas. KTUN bebas adalah KTUN yang didasarkan pada suatu kebebasan bertindak yang lazimnya dikenal dengan asas freies ermessen atau discretionary power. ${ }^{29} \mathrm{Hal}$ ini sesuai dengan Lokakarya tanggal 14 Juli 1990 yang telah menyepakati bahwa AAUPB dapat menilai KTUN yang digugat. ${ }^{30}$ Dengan demikian keabsahan suatu KTUN terikat diuji dengan peraturan tertulis (Peraturan Perundang-undangan), dan untuk keabsahan KTUN bebas diuji dengan AAUPB. Dengan perubahan UU PERATUN, melalui ketentuan

\footnotetext{
${ }^{27}$ Kuntjoro Purbopranoto, Op.Cit., h. 39-40, terjemahan Ridwan HR, Hukum Administrasi Negara, RajaGrafindo Persada, Jakarta, 2006, h. 277-278.

${ }^{28}$ Kuntjoro Purbopranoto, Ibid., h. 35.

${ }^{29}$ Lutfi Effendi, Op.Cit., h. 83.

30 Philiphus M. Hadjon, et.al., Pengantar Hukum Administrasi Indonesia, Gajahmada University Press, Yogyakarta, 1994, h. 145.
}

Pasal 53 ayat (2) diakui secara tegas bahwa salah satu alasan untuk menggugat suatu KTUN adalah karena bertentangan dengan AAUPB.

Terkait dengan uraian tersebut di atas, maka menurut Undang-Undang No. 30 Tahun 2014 tentang Administrasi Pemerintahan (selanjutnya disingkat UUAP) dalam Pasal 8 ayat (2) menyebutkan bahwa Badan dan/atau Pejabat Pemerintahan dalam menggunakan wewenang wajib berdasarkan: (a) peraturan perundang-undangan dan (b) AUPB. Demikian pula dalam Pasal 10 yang mengatur tentang AAUPB menyebutkan:

Pertama, AAUPB yang dimaksud dalam undang-undang ini meliputi: kepastian hukum; kemanfaatan; ketidakberpihakan; kecermatan; tidak menyalahgunakan kewenangan; keterbukaan; kepentingan umum; dan pelayanan yang baik.

Kedua, Asas-asas umum lainnya di luar AUPB sebagaimana dimaksud pada ayat (1) dapat diterapkan sepanjang dijadikan dasar penilaian hakim yang tertuang dalam putusan pengadilan yang berkekuatan hukum tetap.

Dengan demikian AAUPB akan terus berkembang sesuai dengan perkembangan serta dinamika yang ada pada masyarakat dalam suatu negara hukum.

\section{Penyelenggaraan Pemerintah yang Bersih dan Bebas KKN Sebagai Bentuk Pelaksanaan Kesejahteraan Warga Negara Berdasarkan Undang-Undang No. 28 Tahun 1999}

Dalam rangka mewujudkan aparatur atau penyelenggara negara yang professional serta kepemerintahan yang baik, maka tolok ukur pemerintahan yang baik adalah membentuk pelayanan publik yang efisien, efektif dan produktif, peradilan yang handal, serta pemerintah yang bertanggungjawab kepada publiknya dan bebas dari praktek KKN serta perbuatan tercela. Oleh karenanya membangun kepercayaan publik dan menghilangkan citra negatif pada pemerintahan selaku penyelenggara negara, maka diperlukan perubahan-perubahan dalam upaya-upaya untuk menata kembali, menyempurnakan dan atau memperbaiki sistem penyelenggaraan pemerintahan yang baik.

Selanjutnya untuk mewujudkan penyelenggaraan negara yang bersih dan bebas dari korupsi, kolusi dan nepotisme serta dalam rangka menyelamatkan 
dan menormalisasi kehidupan nasional yang sesuai tuntutan reformasi, maka diperlukan adanya kesamaan visi, misi, dan persepsi dari seluruh penyelenggara negara dan masyarakat. Peran serta masyarakat dalam hal ini adalah sesuai dengan hak dan kewajiban yang dimilikinya, maka diharapkan masyarakat dapat lebih bergairah dalam melakukan kontrol sosial yang efektif dan maksimal terhadap penyelenggaraan negara dengan tetap mengingat dan menaati rambu rambu hukum yang berlaku. Sehingga penyelenggara negara dalam melaksanakan kewajibannya benar-benar untuk mewujudkan kesejahteraan masyarakat umum. Oleh karena itu sebagai tolok ukur untuk menilai apakah penyelenggara negara telah sesuai dalam menjalankan tindakannya dalam negara hukum, maka dapat menggunakan AAUPB. Dengan bersandar pada AAUPB dapatlah dipahami sebagai asas-asas umum yang dijadikan sebagai dasar dan tata cara dalam penyelenggaraan pemerintah yang baik, yang dengan cara demikian maka penyelenggaraan negara tersebut menjadi baik, sopan, adil, terhormat, bebas dari kezaliman, pelanggaran peraturan, tindakan penyalahgunaan wewenang atau detournement de pouvoir dan tindakan sewenang-wenang atau willekeur.

Didasarkan pada Pasal 1 UU No. 28 Tahun 1999 tentang Penyelenggara Negara Yang Bersih dan Bebas dari Korupsi, Kolusi, dan Nepotisme, yang dimaksud dengan penyelenggara negara adalah pejabat negara yang menjalankan fungsi eksekutif, legislatif atau yudikatif dan pejabat lain yang fungsi dan tugas pokoknya berkaitan dengan penyelenggaraan negara sesuai dengan ketentuan peraturan perundang-undangan yang berlaku. Terkait dengan ketentuan tersebut di atas, menurut Asmawi Rewansyah mengatakan bahwa penyelenggara pemerintah dalam hal ini adalah pimpinan atau manager pemerintahan yang memiliki berbagai tanggung jawab, antara lain: Tanggung jawab politik (political responsibility) yaitu tanggung jawab melaksanakan politik pemerintah; Tanggung jawab institusional (institutional responsibility) yaitu tanggungjawab untuk melaksanakan dengan baik perintah atasan (tanggung jawab hirarkis); Tanggung jawab kepada masyarakat (public atau popular responsibility) yaitu tanggung jawab terhadap kepentingan masyarakat; Tanggung jawab profesional (profesional responsibility) yaitu tanggung jawab sesuai dengan pertimbangan profesinya; Tanggung jawab keluarga yaitu tanggung jawab sebagai kepala rumah tangga; Tanggung jawab pribadi (personal responsibility) yaitu tanggung jawab berdasarkan kesadaran pribadinya. ${ }^{31}$

Selanjutnya untuk mewujudkan penyelenggaraan negara yang bersih dan bebas KKN diperlukan landasan hukum untuk mencegahnya, maka harus diletakkan asas-asas penyelenggaraan negara. Asas umum penyelenggaraan negara seperti yang termuat pada Pasal 3 UU No. 28 Tahun 1999 yang meliputi: Asas Kepastian Hukum; Asas Tertib Penyelenggaraan Negara; Asas Kepentingan Umum; Asas Keterbukaan; Asas Proporsionalitas; Asas Profesionalitas; Asas Akuntabilitas.

Didasarkan pada UU No. 28 Tahun 1999 terdapat 4 (empat) aspek kebijakan dasar politik nasional yang ditetapkan dalam sistem manajemen kenegaraan RI, dalam rangka menciptakan penyelenggara negara yang bersih dan bebas KKN adalah: Pertama, Meletakkan asas-asas umum penyelenggaraan negara yang baik atau good governance meliputi: asas kepastian hukum, asas tertib penyelenggara negara, asas kepentingan umum, asas keterbukaan, asas proporsionalitas, asas profesionalitas dan asas akuntabilitas. Kedua, Hak dan kewajiban penyelenggara negara, salah satu yang mendasar dan baru adalah menyangkut kewajiban penyelenggara negara melaporkan dan mengumumkan kekayaannya sebelum dan setelah menjabat. Ketiga, Pemeriksaan kekayaan penyelenggara negara sebelum, selama dan setelah menjabat oleh Komisi Pemberantasan Korupsi (KPK). Keempat, Peningkatan peran serta masyarakat dalam penyelenggaraan negara. ${ }^{32}$

Sesuai dengan kebijakan dasar politik nasional dan UU No. 28 Tahun 1999 telah disebutkan tentang peran serta masyarakat untuk mengoptimalkan kegiatan masyarakat untuk ikut serta mengontrol kegiatan penyelenggara negara. Hal ini membuktikan bahwa penyelenggara negara memberikan dan mewujudkan hak dan tanggung jawab masyarakat dalam penyelenggaraan negara yang bebas dan bersih dari KKN. Dengan demikian masyarakat akan memperoleh perlindungan hukum dalam bentuk kebebasan menggunakan hak dan kewajibannya

\footnotetext{
${ }^{31}$ Asmawi Rewansyah, Op.Cit., h. 96-97.

32 Ibid., h. 106-107.
} 
dalam mengemukakan fakta dengan menghormati aturan-aturan sesuai hukum dan peraturan-peraturan yang berlaku.

Namun demikian hukum bukanlah hanya terdiri dari sejumlah peraturan perundang-undangan saja, tetapi hukum merupakan suatu sistem yang terdiri dari unsur-unsur yang saling berkaitan dan saling mempengaruhi, sehingga apabila ada salah satu unsur yang tidak berfungsi maka akan mempengaruhi unsur lainnya. Salah satu tindakan untuk dapat melaksanakan penyelenggaraan pemerintah yang bersih dan bebas dari KKN, maka perlu adanya reformasi hukum dan reformasi struktur. Oleh karenanya masyarakat memiliki peran penting dalam rangka melakukuan kontrol atau pengawasan terhadap penyelenggara negara dan penyelenggara negara diwajibkan untuk memberikan jawaban sesuai tugas dan fungsinya dalam memberikan jawaban yang disampaikan oleh masyarakat.

Reformasi hukum menurut Muktiono mengatakan perlunya reformasi hukum dan reformasi struktur untuk mengantisipasi korupsi agar tercapai penyelenggaraan pemerintahan yang bersih dan bebas KKN meliputi:

Pertama, Reformasi hukum ketatanegaraan (konstitusi) untuk memperkecil monopoli dan diskresi kekuasaan pemerintahan dari tangan presiden, sehingga dimungkinkan adanya power sharing dan check and balance dalam sistem politik kita. Sekarang ini Presiden memilki kekuasaan yang sangat absolut dalam memilih Menteri, Pangab, Kapolri, Jaksa Agung, Gubernur BI, dan lain-lainnya. Bahayanya kalau Presidennya seorang kleptokrat, maka besar kemungkinan terbentuknya rezim kleptokrasi yang memiliki mesin otoritas yang begitu besar.

Kedua, Menjamin adanya transparansi dan akuntabilitas dari pejabat negara atau pemegang kekuasaan publik melalui: a. Kewajiban pejabat negara untuk melaporkan dan diperiksa kekayaannya, pada saat mulai dan berakhir jabatannya (Law Against Illicit Enrichment); b. Kewajiban pejabat membuktikan harta kekayaannya bukan hasil korupsi (asas pembuktian terbalik); c. Kewajiban pejabat negara menyediakan informasi tentang penyelenggaraan negara kepada publik (Public Information Act); d. Perlindungan hukum terhadap pejabat atau masyarakat yang menyampaikan informasi tentang korupsi (Whistie Blower Protection $A c t$ ); e. Wajib melaporkan transaksi keuangan dalam jumlah yang mencurigakan; f. Mengatur asas dan kode etik pejabat publik (Leadership Code of Conduct).

Ketiga, Kriminalisasi suap, baik yang dilakukan oleh private sektor di dalam dan internasional, serta kriminalisasi praktik money laundering (menerima, menyimpan, memindahkan, mentransfer, atau menginvestasi hasil korupsi).

Ketiga, Independen lembaga peradilan. Para hakim jangan lagi tunduk di bawah Menteri Kehakiman, tapi harus di bawah MA, dan MA harus otonom terhadap pemerintah. Independensi aparat penegak hukum, seperti jaksa, polisi, dan para advokat, sangat diperlukan untuk memberantas korupsi.

Keempat, Melengkapi kelembagaan pengawasan korupsi, semacam lembaga Ombudsman (Permanent Commision of Equity) di setiap Kementerian atau Departemen dan Pemda yang dapat berfungsi melakukan penyelidikan dan pemeriksaan terhadap penyimpangan penggunaan kekuasaan atau maladministrasion yang dilakukan oleh pemegang kekuasaan publik dan merekomendasikan perbaikannya.

Kelima, Untuk perkara-perkara korupsi tertentu di mana penyidik atau penuntut tidak dapat melakukan tugas mereka atau tanpa ada kepercayaan masyarakat, harus dimungkinkan dibentuknya jaksa independen (special prosecutor) dan Badan Anti Korupsi (Independence Commision Against Corruption) yang memiliki kewenangan penyelidikan dan menjadi bagian dari sistem peradilan, sehingga jaksa hanya sebagai prosecutor saja.

Keenam, Mengakomodasi keterlibatan civil society dalam pengawasan korupsi secara kontinyu dilakukan oleh semacam lembaga public enquiries dan menjadi bagian dari sistem judicial.

Ketujuh, Adanya prosedur pemeriksaan tidak pidana korupsi (prosedur pemeriksaan khusus), yang memudahkan penuntut menyeret koruptor ke pengadilan. Dan adanya ketentuan-ketentuan khusus untuk memastikan bahwa hasil-hasil korupsi dapat diperoleh kembali oleh negara, khususnya hasilhasil korupsi yang ada di tangan pihak ketiga atau ditempatkan di luar negeri. 
Kedelapan, Keterlibatan masyarakat sipil dalam penyelenggaraan pemerintahan terutama untuk memberantas korupsi benar-benar di uji sekarang ini. LSM, mahasiswa, pers, dan gerakan buruh harus memiliki visi yang sama dalam melakukan pengawasan terhadap penyelenggaraan negara. ${ }^{33}$

Mengenai keterlibatan masyarakat sipil dalam penyelenggaran pemerintah terkait dengan peran serta masyarakat yang dalam hal ini telah sesuai dengan Pasal 8 UU No. 28 Tahun 1999 yang menyebutkan bahwa peran serta masyarakat dalam penyelenggaraan negara merupakan hak dan tanggung jawab masyarakat untuk ikut mewujudkan penyelenggaraan negara yang bersih; Hubungan antara penyelenggaraan negara dan masyarakat dilaksanakan dengan berpegang teguh pada asasasas umum penyelenggaraan negara sebagaimana dimaksud dalam Pasal 3.

\section{Implementasi AAUPB dalam Praktek sebagai Bentuk Pelaksanaan Memajukan Kesejahteraan Masyarakat}

Berbicara tentang penerapan atau pelaksanaan AAUPB dalam tindakan nyata merupakan harapan dan dambaan masyarakat yang berarti adanya pelayanan pada masyarakat terjamin, adil, cepat dan tepat, akurat serta terjangkau oleh masyarakat. Oleh karenanya setiap tindakan administrasi negara harus selalu dilaksanakan berdasarkan hukum yang berlaku, baik hukum yang tertulis maupun hukum yang tidak tertulis dengan tidak membedakan golongan, suku, agama dan bahkan status sosial. AAUPB merupakan hukum yang tidak tertulis. Kondisi ini disebabkan karena konsep pemerintahan yang baik merupakan kebutuhan mutlak bagi rakyat, demi tercipatanya suatu sistem politik pemerintahan yang berpihak kepada kepentingan rakyat sesuai dengan prinsipprinsip demokrasi.

Dalam rangka mewujudkan kepemerintahan yang baik pada pelaksanaannya, maka pemerintah sebagai unsur utama dari penyelenggara pemerintahan yang merupakan pengayom dan pelayan masyarakat sudah seharusnya menjunjung tinggi akan AAUPB sesuai

${ }^{33}$ Irfan Muktiono, "KKN: Identifikasi dan Strategi", Makalah pada Orientasi Good Governance: Sekretaris dan Pimpinan DPRD Kabupaten/Kota, yang diselenggarakan oleh Badan Diklat Depdagri pada tanggal 26-30 Nopember 2001 di Jakarta. dengan ketentuan UU No. 28 Tahun $1999 .{ }^{34}$ Hal ini sesuai dengan ketentuan Pasal 1 ayat (6) yang menyebutkan bahwa AAUPB adalah asas yang menjunjung tinggi norma kesusilaan, kepatutan, dan norma hukum, untuk mewujudkan penyelenggaraan negara yang bersih dan bebas dari KKN.

Pada dasarnya Pemerintah dalam menjalan berbagai kegiatan harus berdasarkan pada peraturan perundang-undangan yang berlaku atau asas legalitas. Keadaan ini karena pemerintah sebagai unsur utama penyelenggara pemerintahan yang merupakan pengayom dan pelayan masyarakat sudah seharusnya menjunjung tinggi AAUPB serta menjalankan tugas dan fungsinya secara optimal. Terkait dengan implementasi AAUPB yang dilaksanakan oleh penyelenggara negara yang bertujuan untuk mewujudkan kesejahteraan masyarakat, maka pemerintah dapat bertindak atas dasar kebijaksanaan untuk menyelenggarakan kepentingan umum.

Menurut Kuntjoro di dalam buku ciptaan Ridwan HR. menyatakan bahwa penyelenggaraan kepentingan umum dapat diwujudkan dengan cara: pertama, memelihara kepentingan umum yang khusus mengenai kepentingan negara, di mana contohnya tugas pertahanan dan keamanan; kedua, memelihara kepentingan umum dalam arti kepentingan bersama dari warga negara yang tidak dapat dipelihara oleh warga negara sendiri yang contohnya adalah persediaan sandang pangan, perumahan, kesejahteraan, dll.; ketiga, memelihara kepentingan bersama yang tidak seluruhnya dapat dilakukan oleh para warga negara sendiri dalam bentuk bantuan negara. Contohnya pendidikan dan pengajaran, kesehatan, dll.; keempat, memelihara kepentingan dari warga negara perseorangan yang tidak seluruhnya dapat diselenggarakan oleh warga negara sendiri, dalam bentuk bantuan negara karena adakalanya negara memelihara seluruh kepentingan perseorangan tersebut yang contohnya adalah pemeliharaan fakir miskin, anak yatim, anak cacat, dll.; kelima, memelihara ketertiban, keamanan dan kemakmuran setempat, yang contohnya adalah peraturan lalu lintas, pembangunan, perumahan, $\mathrm{dll}^{35}$

\footnotetext{
${ }^{34}$ Muhamad Ilham Arisaputra, Penerapan Prinsip-Prinsip Good Governance dalam Penyelenggaraan Reforma Agraria di Indonesia, https://www.academia.edu/10381935/, h. 9, diakes pada tanggal 13 Pebruari 2016.

${ }^{35}$ Ridwan HR, Op.Cit., h. 277-278.
} 
Dengan demikian pengertian kepentingan umum secara sederhana dapat disimpulkan bahwa kepentingan umum untuk keperluan, kebutuhan atau kepentingan orang banyak atau tujuan sosial. Oleh karenanya John Salindeho mengemukakan bahwa yang dimaksud dengan kepentingan umum ialah termasuk kepentingan bangsa dan negara serta kepentingan bersama dari rakyat, dengan memperhatikan segi-segi sosial, politik, psikologis dan hankamnas atas dasar asasasas pembangunan nasional dengan mengindahkan ketahanan nasional serta wawasan nusantara. ${ }^{36}$

Terkait dengan pendapat tersebut di atas, telah tercantum dalam Pasal 3 angka 3 UU No. 28 Tahun 1999 yang dimaksud dengan asas kepentingan umum adalah asas yang mendahulukan kesejahteraan umum dengan cara yang aspiratif, akomodatif dan selektif. Oleh karenanya asas tersebut merupakan konsekwensi dari negara modern yang menganutnya dan menempatkan pemerintah atau penyelenggara negara untuk memajukan serta mewujudkan kesejahteraan masyarakat atau warga negaranya. Hal ini sesuai dengan pendapat Suparto Wijojo yang memberikan contoh tentang diakuinya AAUPB dalam Putusan di PT TUN di Jakarta No. 017/G/1991/ PT.TUN-JKT tanggal 19 Agustus 1992 dengan pertimbangan hakim sebagai berikut: Keputusan tergugat No. 399/386/7-5/XVIII/PHK/9-91 tanggal 7 Agustus 1991 itu bertentangan dengan peraturan perundang-undangan yang ada dan AAUPB yaitu asas keadilan. ${ }^{37}$

\section{PENUTUP}

\section{Kesimpulan}

Berdasarkan pembahasan di atas, maka penyelenggara negara dalam hal ini pemerintah sebagai unsur utama yang merupakan penganyom dan pelayan masyarakat mempunyai peran penting dalam mewujudkan kesejahteraan warga negaranya/ masyarakat. Oleh karena itu sudah seharusnya penyelenggara negara menjunjung tinggi dalam melaksanakan AAUPB serta menjalankan tugas dan fungsinya sesuai dengan ketentuan yang tertuang

36 John Salindeho, Masalah Tanah dalam Pembangunan, Sinar Grafika, Jakarta, 1988, h. 40.

${ }^{37}$ Suparto Wijoyo, Karakter Hukum Acara Peradilan Administrasi (Peradilan Tata Usaha Negara), Airlangga University Press, Surabaya, 2004, h. 14. dalam Undang-Undang No. 28 Tahun 1999 tentang Penyelenggara Negara yang Bersih dan Bebas dari Korupsi, Kolusi, dan Nepotisme, khususnya Pasal 3 yang menyebutkan asas kepastian hukum, asas tertib penyelenggaraan negara, asas kepentingan umum, asas keterbukaan, asas proposionalitas, asas profesionalitas dan asas akuntabilitas, sehingga terciptalah tata pemerintahan yang bersih dan berwibawa.

Adapun konsep tentang peran serta masyarakat melalui hak dan kewajibannya sebagai pemegang kedaulatan tertinggi negara akan mendapatkan informasi, pelayanan yang merupakan dambaan dan harapan masyarakat sesuai dengan ketentuan peraturan perundang-undangan yang berlaku serta melakukan kontrol secara optimal terhadap penyelenggara negara dengan menaati ramburambu hukum yang telah ditetapkan. Dengan demikian akan menimbulkan kepercayaan pada pihak penyelenggara negara. Kepercayaan inilah yang menjadi simbol sehingga terjadi kerjasama antara pihak penyelenggara negara dengan warga negara. Titik temu dengan adanya kepercayaan antara pihak penyelenggara negara dan warga negara/ masyarakat adalah demi kepentingan umum, yang artinya adalah di dalam setiap kegiatan kehidupan sehari hari, berbangsa dan bernegara adalah untuk kepentingan rakyat/warga negara, bukan untuk kepentingan golongan, kelompok, ataupun pribadi secara individual.

Dengan demikian untuk mewujudkan kedaulatan rakyat atau warga negara pada seluruh sendi kehidupan bermasyarakatan, berbangsa dan bernegara melalui perluasan dan peningkatan partisipasi politik rakyat secara tertib, apabila penyelenggara negara melaksanakan AAUPB sesuai dengan ketentuan Pasal 10 ayat (1) UUAP yang menyebutkan adanya kepastian hukum, kemanfaatan, ketidakberpihakan, kecermatan, tidak menyalahgunakan kewenangan, keterbukaan, kepentingan umum, dan pelayanan yang baik.

\section{Rekomendasi}

Penerapan konsep AAUPB merupakan kebutuhan mutlak baik bagi penyelenggara negara dan masyarakat atau warga negara, dengan mengutamakan prinsip-prinsip demokrasi, maka tahapan-tahapan dan langkah-langkah konkrit 
untuk mewujudkan kesejahteraan warga negara haruslah segera dilaksanakan, karena tindakan ini merupakan konsekuensi penyelenggara negara dalam menyelenggarakan dan mewujudkan kesejahteraan umum sebagai kepentingan segenap bangsa. Warga negara harus turut berpartisipasi dalam mengontrol dan melakukan pengawasan terhadap penyelenggara negara dalam melaksanakan AAUPB untuk mendapatkan pelayanan yang berkualitas.

\section{DAFTAR PUSTAKA}

\section{Peraturan Perundang-undangan:}

Undang-Undang Dasar Republik Indonesia 1945.

Undang-Undang Nomor 28 Tahun 1999 tentang Penyelenggaraan Negara yang Bersih dan Bebas dari Korupsi, Kolusi, dan Nepotisme, Lembaran Negara Tahun 1999 Nomor 75, Tambahan Lembaran Negara Nomor 3851.

Undang-Undang Nomor 14 Tahun 2008 tentang Keterbukaan Informasi Publik, Lembaran Negara Tahun 2008 Nomor 61, Tambahan Lembaran Negara Nomor 4846.

Undang-Undang Nomor 12 Tahun 2011 tentang Pembentukan Peraturan Perundang-Undangan, Lembaran Negara Tahun 2011 Nomor 82, Tambahan Lembaran Negara Nomor 5234.

Undang-Undang Nomor 30 Tahun 2014 tentang Administrasi Pemerintahan, Lembaran Negara Tahun 2014 Nomor 292, Tambahan Lembaran Negara Nomor 5601.

Peraturan Pemerintah Nomor 68 Tahun 1999 tentang Tata Cara Pelaksanaan Peran Serta Masyarakat dalam Penyelenggaraan Negara.

Keputusan Presiden Republik Indonesia Nomor 127 Tahun 1999 tentang Pembentukan Komisi Pemeriksa Kekayaan Penyelenggara Negara dan Sekretariat Jenderal Komisi Pemeriksa Kekayaan Penyelenggara Negara.

\section{Buku:}

Djatmiati, Tatiek Sri, "Peradilan Tata Usaha Negara dalam Konteks Undang-Undang Nomor 30 Tahun 2014 tentang Administrasi Pemerintahan", dalam Makalah yang disampaikan pada Seminar Nasional Kewenangan PTUN Pasca Diundangkannya UU AP Nomor 30 Tahun 2014, diselenggarakan FH Unair, 29 Agustus 2016, Surabaya.
Efendi, Aan, 2011, Buku Ajar Acara Peradilan Tata Usaha Negara, Jember: UNEJ.

Effendi, Lutfi, 2004, Pokok-Pokok Hukum Administrasi, Malang: Bayu Media.

Fahmal, Muin, 2008, Peran Asas-asas Umum Pemerintahan yang Layak dalam Mewujudkan Pemerintahan yang Bersih. Yogyakarta: UII Press.

Hamidi, Jazim, 1999, Penerapan Asas-asas Umum Penyelenggaraan Pemerintahan yang Layak (AAUPL) di Lingkungan Peradilan Administrasi Indonesia, Bandung: Citra Aditya Bakti, terjemahan Nomensen Sinano, 2010, Hukum Administrasi Negara, Jakarta: Jala Permata Aksara.

HR., Ridwan, 2008, Hukum Administrasi Negara, Jakarta: Rajagrafindo Persada.

Indroharto, 2005, Usaha Memahami UndangUndang tentang Peradilan Tata Usaha Negara, Buku II Beracara di Pengadilan Tata Usaha Negara, Jakarta: Pustaka Sinar Harapan.

Lotulung, Paulus Efendi, 1994, Himpunan Asasasas Umum Pemerintahan yang Baik (AAUPB), Bandung: Citra Aditya Bakti. , 1994, (ed) Himpunan Makalah Asas-asas Umum Pemerintahan yang Baik, Bandung: Citra Aditya Bakti.

, Yurisprudensi dalam Perspektif Pengembangan Hukum Administrasi Negara di Indonesia, Makalah Pidato Pengukuhan Guru Besar Fakultas Hukum Universitas Pakuan, Bogor 24 September 1994.

Lukman, Markus, 1989, "Freis Ermessen Dalam Proses Perencanaan dan Pelaksanaan Rencana Kota di Kotamadya Pontianak", Tesis tidak diterbitkan, Bandung: Universitas Padjadjaran.

M. Hadjon, Philiphus, et.al., 1994, Pengantar Hukum Administrasi Indonesia, Yogyakarta: Gadjahmada University Press.

, "Pemerintahan Menurut Hukum (Wet-en Rechtmatigheid van Bestuur)", Makalah tidak Dipublikasikan. , "Fungsi Normatif Hukum Administrasi dalam Mewujudkan Pemerintahan yang Bersih", Makalah disampaikan pada Orasi Guru Besar Ilmu Hukum, Fakultas Hukum Universitas Airlangga, Surabaya, 10 Oktober 1994. 
Marbun, S.F., 2011, Peradilan Administrasi Negara dan Upaya Administratif di Indonesia, Cet. III, Yogyakarta: FH UII Press.

Marzuki, Peter Mahmud, 2010, Penelitian Hukum, Cetakan VI, Jakarta: Kencana Prenada Media Group.

Muktiono, Irfan, "KKN: Identifikasi dan Strategi”, Makalah pada Orientasi Good Governance: Sekretaris dan Pimpinan DPRD Kabupaten/ Kota yang diselenggarakan oleh Badan Diklat Depdagri pada tanggal 26-30 Nopember 2001 di Jakarta.

Purbopranoto, Kuntjoro, 1975, Beberapa Catatan Hukum Tata Pemerintahan dan Peradilan Administrasi Negara, Bandung: Bina Cipta.

Rewansyah, Asmawi, 2010, Reformasi Birokrasi dalam Rangka Good Governance, Jakarta: Yusaintanas Prima, h. 99, dikutip dari Mustopadidjaja, AR, 2005, Dimensi-dimensi Pokok Sistem Administrasi Negara Kesatuan Republik Indonesia, Cetakan Kelima. Jakarta: Duta Pertiwi Foundation.

Salindeho, John, 1988, Masalah Tanah dalam Pembangunan, Jakarta: Sinar Grafika.

Sibuea, Hotma P., 2002, Asas Negara Hukum Peraturan Kebijakan dan Asas-asas Umum Pemerintahan yang Baik, Jakarta: Erlangga.

Sinamo, Nomensen, 2010, Hukum Administrasi Negara, Jakarta: Jala Permata Aksara.
Sugiharto, Hari, "Pemeriksaan Hakim PTUN terhadap Perluasan (Expantion) Kewenangan PTUN sebagai Implementasi UU No. 30 Tahun 2014 tentang Administrasi Pemerintahan", dalam Makalah yang disampaikan pada Seminar Nasional dengan tema Aspek Kewenangan Peradilan Tata Usaha Negara Pasca Diundangkannya Undang-Undang Nomor 30 Tahun 2014 tentang Administrasi Pemerintahan, diselenggarakan FH Unair Surabaya, 29 Agustus 2016.

Syarifuddin, Ateng, Asas-asas Pemerintahan yang Layak bagi Pengabdian Kepala Daerah, dalam Paulus Efendi Lotulung, 1994, Himpunan Asasasas Umum Pemerintahan yang Baik (AAUPB), Bandung: Citra Aditya Bakti.

Wijoyo, Suparto, 1999, Penyelesaian Sengketa Lingkungan (Environmental Disputes Resolution), Surabaya: Airlangga University Press.

\section{Website:}

Arisaputra, Muhamad Ilham, Penerapan Prinsip-prinsip Good Governance dalam Penyelenggaraan Reforma Agraria di Indonesia, https://www.academia.edu/10381935/, diakes pada tanggal 13 Pebruari 2016. 